\title{
A Review of Novel Non-Nucleoside Anti-HBV Agents and Their Mechanism of Action
}

\author{
Sheng Liu and Yubin Li* \\ College of Science, Guangdong Ocean University, Zhanjiang, 524088, P. R. China
}

\begin{abstract}
Hepatitis B virus (HBV) infection is a serious worldwide health problem as drugs (such as lamivudine and adefovir) for treating HBV are still unsatisfactory, due to high recurrence, drug resistance and inevitable side effects. Therefore, there exists a significant medical need to explore novel classes of drugs with different antiviral targets and mechanisms for anti-HBV purposes. Recently, some non-nucleoside HBV inhibitors with specific targets have been obtained from natural sources or prepared by synthesis. These compounds provide useful information for developing novel non-nucleoside compounds as anti-HBV agents.
\end{abstract}

Keywords: Hepatitis B virus; Non-nucleoside; Anti-HBV drugs; Targets

\section{Introduction}

Hepatitis B virus (HBV) is a severe public health problem in the world, which is caused by hepatitis B virus (HBV) [1,2]. According to the World Health Organization (WHO) reports, more than 400 million people are chronically infected with $\mathrm{HBV}$ worldwide and about 1 million people are estimated to die of $\mathrm{HBV}$-infected diseases per year, including cirrhosis, liver failure, and hepatocellular carcinoma $[3,4]$. Currently available options for the treatment strategies for patients with chronic hepatitis $\mathrm{B}(\mathrm{CHB})$ include interferons (interferon-alpha and pegylated interferon) and nucleos(t)ide analogue antiviral agents (lamivudine, entercavir, adefovir dipivoxil, telbivudine and tenofovir) [5]. Interferon alpha, a cytokine, is one of the signaling proteins with the underlying mechanism of immunomodulation. Nucleos(t)ide analogs are polymerase inhibitors that target DNA elongation by inhibiting the reverse transcription of HBV [6]. However, these anti-HBV drugs are still unsatisfactory, due to their limitations. For example, interferonalpha has limited efficacy and high incidence of adverse reactions. The nucleoside analogues are efficient, but long-term use of these agents may result in drug resistance and recurrence in a significant number of patients and the HBV genome can't be eradicated [7,8]. In the last decade, the therapeutic use of the anti-HBV agents such as interferonalpha and nucleos(t)ide analogs have developed and made great progress. For example, HBV may be eradicated. However, the purpose, including clearance of HBV DNA and seroconversion of hepatitis B surface antigen (HBsAg) to anti-HBs, still remain impossible at present. Therefore, there exists a significant unmet medical need to explore novel classes of drugs with different antiviral targets and mechanisms for anti-HBV purposes. Many classes of non-nucleoside compounds by isolation or synthesis have been showing promising activity against HBV. But little is referred to the mechanisms. Therefore, this review will focus on the novel targets and the progress of related small molecule of non-nucleoside HBV inhibitors under development and evaluation.

\section{Novel Targets and Related Drugs}

\section{Core protein (HBcAg)}

HBV contains a $3.2 \mathrm{~kb}$ partially double-stranded DNA genome with four open reading frames (ORFs) encoding four viral proteins including core protein $(\mathrm{Cp})$, surface protein $(\mathrm{S})$, polymerase $(\mathrm{P})$, and $\mathrm{X}$ protein $(\mathrm{X})$ [9]. Core protein mainly constitutes the nucleocapsid which harbors the viral DNA and polymerase [10]. It was reported that dominant negative core protein mutants, which could not support pregenomic RNA packaging and genome maturation, could effectively inhibit replication of HBV [11]. The envelopment of virus particles was interrelated to the interactions between $\mathrm{HBV}$ surface proteins and core proteins, and blocking these interactions may serve as a novel anti-HBV strategy $[12,13]$. Two promising anti-HBV drug candidates KKJ00626 and KSG00011 (Figure 1), were found to inhibit the production of HBV particles in Huh-7 cells transfected with HBV DNA by blocking the interactions between HBV surface proteins and core proteins [14].

Lignan helioxanthin and helioxanthin analogs (Figure 2) were reported to possess potential anti-HBV activity with a unique antiHBV mechanism $[15,16]$. It was found to inhibit the gene expression and HBV DNA replication in wild-type and lamivudine-resistant mutants. The luciferase reporter assay results showed that HE-145 inhibited selectively core promoter $(\mathrm{CP})$ and surface antigen promoter II (SPII), but had no effect on X gene promoter (Xp) and surface antigen promoter I (SPI). Besides, their anti-HBV efficiencies in vivo warranted further investigation. The lignans niranthin and nirtetralin B (Figure 3) from Phyllanthus niruri L. were reported to possess obvious anti-hepatitis B virus activity both in vitro and vivo $[17,18]$. The treatment of HBV-transfected HepG2.2.15 cells with niranthin or nirtetralin $\mathrm{B}$ exhibited a dose-dependent inhibitory effect not only on the secretion of $\mathrm{HBsAg}$ and $\mathrm{HBeAg}$ antigens but also on the replication of HBV DNA. Niranthin and nirtetralin B were found to show antiHBV activity and hepatoprotective effect in HBV infected ducks. For further study, a series of analogues were synthesized based on these two ligands and their potential anti-HBV activity was evaluated [19-21]. Their potential anti-HBV activity was evaluated. The results showed that some of the analogues displayed inhibiting not only HBsAg and HBeAg secretion but also HBV DNA replication, compared with 3TC which showed significantly activity against HBV DNA replication while showing little inhibitory effect on HBsAg and HBeAg secretion. In addition, the docking results and measurement of the interaction indicatied that the anti-HBV effect of these analogues may exert its anti-HBV activity by inhibiting $\mathrm{HBcAg}$.

*Corresponding author: Yubin $\mathrm{Li}$, College of Science, Guangdong Ocean University, Zhanjiang, 524088, P. R. China, Fax: +918212476997; E-mail: liusheng87@126.com

Received July 11, 2016; Accepted July 19, 2016; Published July 25, 2016

Citation: Liu S, Li Y (2016) A Review of Novel Non-Nucleoside Anti-HBV Agents and Their Mechanism of Action. Med Chem (Los Angeles) 6: 521-524. doi:10.4172/2161-0444.1000393

Copyright: @ 2016 Liu S, et al. This is an open-access article distributed under the terms of the Creative Commons Attribution License, which permits unrestricted use, distribution, and reproduction in any medium, provided the original author and source are credited. 
<smiles>Cc1cc(C)n2nc(S)nc2n1</smiles>

Figure 1: Structure of KKJ00626 and KSG 00011.

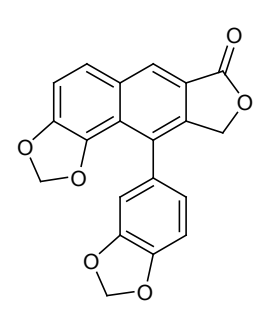

helioxanthin

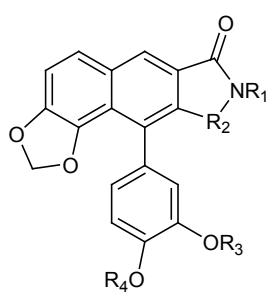

$\mathrm{R}_{1}=\mathrm{H}, \mathrm{CH}_{3}, \mathrm{NHAc} ; \mathrm{R}_{2}=\mathrm{CO}, \mathrm{CH}_{2}, \mathrm{CONH}$ $\mathrm{R}_{3}=\mathrm{R}_{4}=\mathrm{CH}_{3}$ or $\mathrm{R}_{3}, \mathrm{R} 4=-\mathrm{CH}_{2}$ -
Figure 2: Lignan helioxanthin and helioxanthin analogs.

$$
\text { niranthin }
$$

Figure 3: Lignan niranthin and nirtetralin B and their analogs.

3,4-O-dicaffeoylquinic acid and 3,5-O-dicaffeoylquinic acid (Figure 4) could markedly decrease the HBV cccDNA content in HepG2.2.15 cells and HBV transgenic mice. HO- 1 was found to destabilize the HBV core protein, suggesting that overexpression of HO-1 may contribute to the antiviral activity by decreasing the stability of the HBV core protein, which blocks the refill of nuclear HBV cccDNA [22,23].

\section{Surface protein (HBsAg)}

HBsAg acts as an anti-HBV target based on the HBV-specific immune response. Obviously, HBsAg could elicit production of neutralizing antibodies. However, HBsAg is overwhelmingly produced and stably maintained in chronically $\mathrm{HBV}$-infected patients, leading to the suppression of an $\mathrm{HBV}$-specific immune response. Besides, $\mathrm{HBsAg}$ is required for assembling of viral particles. Aromatically substituted tetrahydro-tetrazolo-(1,5-a)-pyrimidine (HBF-0259) (Figure 5) was a molecule inhibitor of HBsAg secretion [24]. It's reported that HBF0259 show its anti-HBV activity by inhibiting the secretion of $\mathrm{HBsAg}$ bearing subviral particles and DNA-containing viral particles, not the HBeAg secretion and HBV replication in HepG2.2.15 cells.

\section{Heat stress cognate 70 (Hsc70)}

Due to limited ability of HBV replication, the replication cycle is relied on the host protein, in which heat stress cognate 70 (Hsc70) may play an important role in the HBV replication. Hsc70 is positively correlated with HBV replication. It is an essential protein for HBV replication, but not essential for cell survival. Thus, the inhibition of expression of Hsc70 protein may contribute to the inhibition of $\mathrm{HBV}$ replication.

Oxymatrine (Figure 6), an alkaloid from the herb Sophora alopecuraides L., was reported to exhibit anti-HBV effect in HBV transgenic mice $[25,26]$ and patients with chronic HBV infection [27]. The antiviral mechanisms may be interfering with the reverse transcription process from pgRNA to DNA by destabilizing Hsc70 mRNA, and then inhibiting the replication of HBV [28]. Cepharanthine hydrochloride $(\mathrm{CH})$ (Figure 7 ), a natural alkaloid, was reported to suppress $\mathrm{HBeAg}$ production and HBV DNA replication by downregulatng significantly the Hsc70 mRNA levels, indicating that its activity could be associated with its inhibitory effect on host Hsc70 [29].

\section{HBV polymerase}

HBV polymerase plays an important role in the viral replication cycle and is a key target of anti-HBV chemotherapy. The DNA polymerase activity needed two essential enzymatic activities, including conversion of pgRNA to the DNA copy and RNase $\mathrm{H}$ activity. The TP domain of $\mathrm{HBV}$ polymerase was a protein primer to form a stable ribonucleoprotein in the viral RNA packaging, and was reported to plays a critical dual role in the protein-primed initiation of viral reverse transcription and in nucleocapsid assembly. So it could serve<smiles>O=C(/C=C/c1ccc(O)c(O)c1)O[C@H]1C[C@](O)(C(=O)O)C[C@H](O)[C@H]1OC(=O)/C=C/c1ccc(O)c(O)c1</smiles>

3,4-O-dicaffeoylquinic acid<smiles>O=C(/C=C/c1ccc(O)c(O)c1)O[C@H]1CC(O)(C(=O)O)C[C@H](OC(=O)/C=C/c2ccc(O)c(O)c2)C1O</smiles>

3,5-O-dicaffeoylquinic acid
Figure 4: 3,4-O-dicaffeoylquinic acid and 3,5-O-dicaffeoylquinic acid.<smiles>O=[R6]=Nc1nnn2c1C(c1ccc(Cl)cc1)CC2c1c(F)cccc1Cl</smiles>

Figure 5: Tetrahydro-tetrazolo-(1,5-a)-pyrimidine.<smiles>CC12C3CCCN1CCCC2[C@@H]1CCCC(=O)N1C3</smiles>

Figure 6: Structure of oxymatrine. 
as a target for anti-HBV agents. Iron protoporphyrin IX (hemin) and several related porphyrin compounds (Figure 8) were found to block the interaction of polymerase-e by targeting the TP domain of the $\mathrm{HBV}$ polymerase, thus blocking the protein-priming reaction and viral reverse transcription [30].

\section{HBV PgRNA}

Pregenomic RNA could recognize reverse transcriptase $\mathrm{P}$ and trigger the HBV replication. The combination of small molecule and pgRNA would disturb the replication of RNA, resulting in that the virus cannot assemble and replicate according to the original way. Thus, pgRNA could be served as a novel target $[31,32]$.

1-Deoxynojirimycin (DNJ) and its derivatives possessed anti-HBV activity by a mechanism of preventing the proper encapsidation of the HBV pgRNA [33-36]. Phenylpropenamides, such as AT-61 and AT130 (Figure 9), were shown to inhibit HBV replication by interfering with viral pgRNA encapsidation and packaging $[37,38]$.

\section{HBV receptors}

Lutein (Figure 10), a major dietary carotenoid, was found to show anti-HBV activity by reducing both $\mathrm{HBsAg}$ and $\mathrm{HBeAg}$ secretion and extracellular HBV DNA levels in HepG2.2.15 cells. The activity involved the inhibition of the HBV full-length promoter [39].

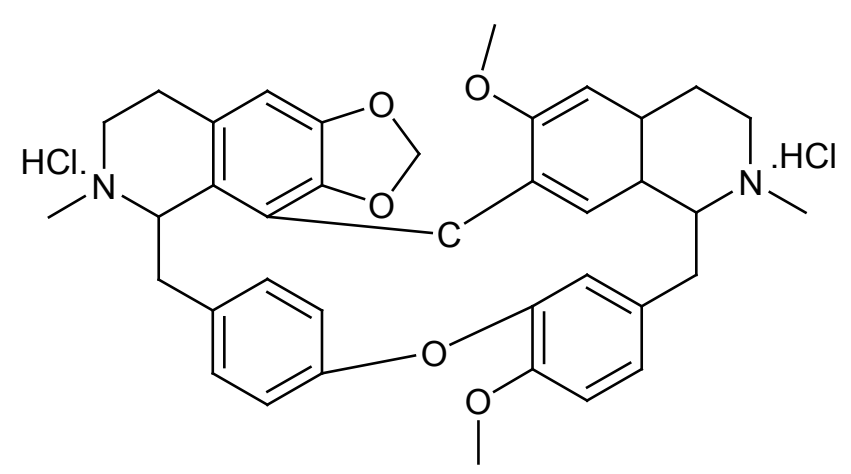

Figure 7: Cepharanthine hydrochloride $(\mathrm{CH})$.

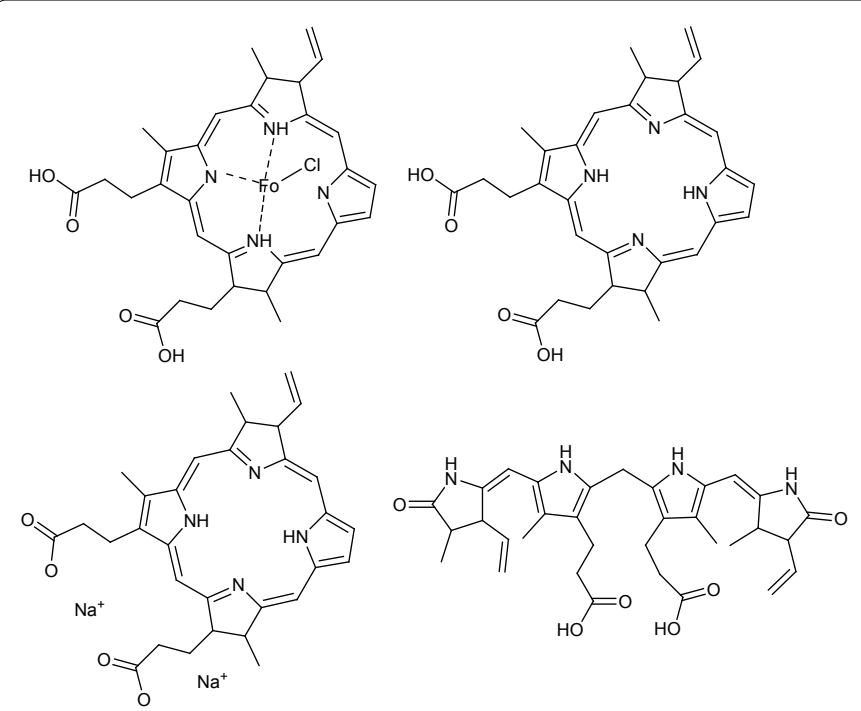

Figure 8: Iron protoporphyrin IX (hemin) and several related porphyrin compounds.<smiles>O=C(N/C(C(=O)N1CCCCC1)=C(/Cl)c1ccccc1)c1ccccc1</smiles>

AT-61<smiles>COc1ccccc1/C(Br)=C(\NC(=O)c1ccc([N+](=O)[O-])cc1)C(=O)N1CCCCC1</smiles>

AT-130
Figure 9: Phenylpropenamides AT-61 and AT-130.<smiles>C[C@@H]1O[C@H](OC[C@H]2C[C@H](Oc3c(-c4ccc(O)c(O)c4)oc4cc(O)cc(O)c4c3=O)[C@@H](O)[C@H](O)[C@@H]2O)[C@H](O)[C@H](O)[C@H]1O</smiles>

Figure 10: Structure of lutein.

\section{Conclusion}

Currently, due to drug resistance, lower response rate, and adverse side-effects of current anti-HBV drugs, novel and effective anti-HBV agents with different antiviral targets and mechanisms are needed to be explored. Many non-nucleoside HBV inhibitors have been found for their promising and potent inhibitory effects against HBV, but most studies have focused primarily on evaluating their anti-HBV activities, with little attention applied to their respective targets and mechanisms of action. Therefore, they should be included in further experimental and clinical investigations in order to promote the new anti-HBV drug discovery and development for the hepatitis B infection treatment.

\section{Acknowledgements}

This work was financially supported by the national natural science foundation of China, natural science foundation of Guangxi province, China, and science research and technology development foundation of Guagnxi province, China.

\section{References}

1. Dienstag JL (2008) Hepatitis B virus infection. N Engl J Med 359: 1486-1500.

2. Lavanchy D (2004) Hepatitis B virus epidemiology, disease burden, treatment and current and emerging prevention and control measures. J Viral Hepat 11 97-107.

3. Ocama P, Opio CK, Lee WM (2005) Hepatitis B virus infection: current status Am J Med 118: 1413.

4. Ganem D, Prince AM (2004) Hepatitis B virus infection--natural history and clinical consequences. N Engl J Med 350: 1118-1129.

5. Papatheodoridis GV, Manolakopoulos S, Dusheiko G, Archimandritis AJ (2008) Therapeutic strategies in the management of patients with chronic hepatitis $B$ virus infection. Lancet Infect Dis 8: 167-178.

6. Wu X, Jia J, You H (2015) Thymosin alpha-1 treatment in chronic hepatitis B Expert Opin Biol Ther 15: S129-S132. 
7. Zoulim F (2011) Hepatitis B virus resistance to antiviral drugs: where are we going? Liver Int 31: 111-116.

8. Sato K, Mori M (2010) Current and novel therapies for hepatitis B virus infection. Mini Rev Med Chem 10: 20-31.

9. Nassal M (2008) Hepatitis B viruses: reverse transcription a different way. Virus Res 134: 235-249.

10. Crowther RA, Kiselev NA, Böttcher B, Berriman JA, Borisova GP, et al. (1994) Three-dimensional structure of hepatitis $B$ virus core particles determined by electron cryomicroscopy. Cell 77: 943-950.

11. Scaglioni P, Melegari M, Takahashi M, Chowdhury JR, Wands J (1996) Use of dominant negative mutants of the hepadnaviral core protein as antiviral agents. Hepatology 24: 1010-1017.

12. Löffler-Mary H, Dumortier J, Klentsch-Zimmer C, Prange R (2000) Hepatitis B virus assembly is sensitive to changes in the cytosolic $S$ loop of the envelope proteins. Virology 270: 358-367.

13. Choi KJ, Lim CW, Yoon MY, Ahn BY, Yu YG (2004) Quantitative analysis of the interaction between the envelope protein domains and the core protein of human hepatitis B virus. Biochem Biophys Res Commun 319: 959-966.

14. Asif-Ullah M, Choi KJ, Choi KI, Jeong YJ, Yu YG (2006) Identification of compounds that inhibit the interaction between core and surface protein of hepatitis B virus. Antiviral Res 70: 85-90.

15. Tseng YP, Kuo YH, Hu CP, Jeng KS, Janmanchi D, et al. (2008) The role of helioxanthin in inhibiting human hepatitis $B$ viral replication and gene expression by interfering with the host transcriptional machinery of viral promoters. Antiviral Res 77: 206-214.

16. Yeo H, Li Y, Fu L, Zhu JL, Gullen EA, et al. (2005) Synthesis and antiviral activity of helioxanthin analogues. J Med Chem 48: 534-546.

17. Liu S, Wei WX, Shi KC, Cao X, Zhou M, et al. (2014) In vitro and in vivo antihepatitis $B$ virus activities of the lignan niranthin isolated from Phyllanthusniruri L. J Ethnopharmacol 155: 1061-1067.

18. Liu S, Wei WX, Li YB, Lin X, Shi KC, et al. (2014) In vitro and in vivo anti-hepatitis $B$ virus activities of the lignan nirtetralin $B$ isolated from Phyllanthusniruri $L$. J Ethnopharmacol 157: 62-68.

19. Liu S, Wei WX, Li YB, Liu X, Cao XJ, et al. (2015) Design, synthesis, biological evaluation and molecular docking studies of phenylpropanoid derivatives as potent anti-hepatitis B virus agents. Eur J Med Chem 95: 473-482.

20. Liu S, Li Y, Wei W, Wang K, Wang L, et al. (2016) Design, synthesis, molecular docking studies and anti-HBV activity of phenylpropanoid derivatives. Chem Biol Interact 251: 1-9.

21. Liu S, Li YB, Wei WX, Wei JC (2016) Synthesis and biological evaluation of phenylpropanoid derivatives. Med Chem Re 25: 1074-1086.

22. Hao BJ, Wu YH, Wang JG, Hu SQ, Keil DJ, et al. (2012) Hepatoprotective and antiviral properties of isochlorogenic acid $A$ from Laggera alata against hepatitis B virus infection. J Ethnopharmacol 144: 190-194.

23. Wu YH, Hao BJ, Cao HC, Xu W, Li YJ, et al. (2012) Anti-hepatitis B virus effect and possible mechanism of action of 3,4-o-dicaffeoylquinic Acid in vitro and in vivo. Evid Based Complement Alternat Med 2012: 356806.
24. Dougherty AM, Guo H, Westby G, Liu Y, Simsek E, et al. (2007) A substituted tetrahydro-tetrazolo-pyrimidine is a specific and novel inhibitor of hepatitis $B$ virus surface antigen secretion. Antimicrob Agents Chemother 51: 4427-4437.

25. Chen XS, Wang GJ, Cai X, Yu HY, Hu YP (2001) Inhibition of hepatitis B virus by oxymatrine in vivo. World J Gastroenterol 7: 49-52.

26. Lu LG, Zeng MD, Mao YM, Fang JY, Song YL, et al. (2004) Inhibitory effect of oxymatrine on serum hepatitis B virus DNA in HBV transgenic mice. World $J$ Gastroenterol 10: 1176-1179.

27. Lu LG, Zeng MD, Mao YM, Li JQ, Wan MB, et al. (2003) Oxymatrine therapy for chronic hepatitis $\mathrm{B}$ : a randomized double-blind and placebo-controlled multicenter trial. World J Gastroenterol 9: 2480-2483.

28. Wang YP, Liu F, He HW, Han YX, Peng ZG, et al. (2010) Heat stress cognate 70 host protein as a potential drug target against drug resistance in hepatitis $B$ virus. Antimicrob Agents Chemother 54: 2070-2077.

29. Zhou YB, Wang YF, Zhang Y, Zheng LY, Yang XA, et al. (2012) In vitro activity of cepharanthine hydrochloride against clinical wild-type and lamivudine-resistant hepatitis B virus isolates. Eur J Pharmacol 683: 10-15.

30. Lin L, Hu J (2008) Inhibition of hepadnavirus reverse transcriptase-epsilon RNA interaction by porphyrin compounds. J Virol 82: 2305-2312.

31. Thomas JR, Hergenrother PJ (2008) Targeting RNA with small molecules Chem Rev 108: 1171-1224.

32. Blount KF, Breaker RR (2006) Riboswitches as antibacterial drug targets. Nat Biotechnol 24: 1558-1564.

33. Block TM, Lu X, Platt FM, Foster GR, Gerlich WH, et al. (1994) Secretion of human hepatitis $B$ virus is inhibited by the imino sugar $\mathrm{N}$-butyldeoxynojirimycin. Proc Natl Acad Sci U S A 91: 2235-2239.

34. Mehta A, Lu X, Block TM, Blumberg BS, Dwek RA (1997) Hepatitis B virus (HBV) envelope glycoproteins vary drastically in their sensitivity to glycan processing: evidence that alteration of a single $\mathrm{N}$-linked glycosylation site can regulate HBV secretion. Proc Natl Acad Sci U S A 94: 1822-1827.

35. Lazar C, Durantel D, Macovei A, Zitzmann N, Zoulim F, et al. (2007) Treatment of hepatitis $B$ virus-infected cells with alpha-glucosidase inhibitors results in production of virions with altered molecular composition and infectivity. Antiviral Res 76: 30-37.

36. Mehta A, Carrouée S, Conyers B, Jordan R, Butters T, et al. (2001) Inhibition of hepatitis $B$ virus DNA replication by imino sugars without the inhibition of the DNA polymerase: therapeutic implications. Hepatology 33: 1488-1495.

37. Katen SP, Chirapu SR, Finn MG, Zlotnick A (2010) Trapping of hepatitis B virus capsid assembly intermediates by phenylpropenamide assembly accelerators. ACS Chem Biol 5: 1125-1136.

38. Billioud G, Pichoud C, Puerstinger G, Neyts J, Zoulim F (2011) The main hepatitis $B$ virus (HBV) mutants resistant to nucleoside analogs are susceptible in vitro to non-nucleoside inhibitors of HBV replication. Antiviral Res 92: 271 276.

39. Pang R, Tao JY, Zhang SL, Zhao L, Yue X, et al. (2010) In vitro antiviral activity of lutein against hepatitis B virus. Phytother Res 24: 1627-1630. 